\title{
ON THE EDGE OF THE CIVILIZED WORLD: CYRUS HAMLIN AND THE AMERICAN MISSIONARY WORK IN TURKEY
}

\author{
HIMMET UMUNÇ*
}

While he was yet a third-year student at Bangor Theological Seminary in Maine, Cyrus Hamlin received a letter, dated February 4, 1837, from Rev. Dr. William Armstrong of the Prudential Committee, the American Board of Commissioners for Foreign Missions, Boston (Hamlin, 1924, p. 158). The letter informed him that he had been assigned as a missionary to Istanbul in order, as he pointed out later in his memoirs, "to take charge of a high school... and give myself to the work of education" (Hamlin, 1877, p. 28). Although he had been expecting to be assigned to China, he welcomed his transfer to Istanbul with equal satisfaction and was especially thrilled by the prospect that his assignment would provide him with the unique opportunity to work with what he called the "excellent and noble associates" of the American mission in Turkey, whose reports and news he had read "with so much interest that I felt acquainted with them" (Hamlin, 1924, p. 159). The missionaries that he so enthusiastically looked forward to being associated with were William Goodell, Harrison Gray Otis Dwight, William G. Schauffler, Henry A. Holmes, Benjamin Schneider, and Philander O. Powers, who had, as the founding fathers of the missions in Turkey, played a very important role in the development and expansion of the missionary effort throughout Turkey and in other parts of the Ottoman Empire. Therefore, on receiving the letter Hamlin got into an ecstatic mood and, in his memoirs afterwards, described his ecstasy as follows:

I was profoundly affected by thus being taken up by the Spirit and instantly transferred from China to the Bosphorus. It seemed as though some physical influence had descended upon me from the clouds. I hastened to my room, and was glad I could be alone; my chum was out. I took the map, and contemplated the route (Hamlin, 1924, pp. 158-59).

\footnotetext{
* Prof. Dr., Department of English Language and Literature, Hacettepe University, Ankara.
} 
In fact, he contemplated not only the route, which he thought was constantly being traversed by "rum and missionary" merchant ships, but also Istanbul itself which, for him, was a city "on the borders of civilization" (Hamlin, 1924, p. 159). Since he had never been to Turkey before, and since all that he knew about Turkey, its people and culture, had mainly been derived from missionary sources, travel narratives, and historiographical and other types of writing, his reference to Istanbul as a city situated on the edge of the civilized world, which for him was Europe, was understandably coloured by his cultural solipsism, religious parochialism, and sense of oriental otherness. This initial vision he had of Istanbul and, indeed, of Turkey on the whole, was hardly altered through his experiences and observations of the country during his long stay in Istanbul of over thirty five years as a leading missionary and educator. For him, Istanbul, whose "streets were filled... with crowds of strangely dressed people", was inhabited by an "insane, vociferating multitude" (Hamlin, 1924, p. 181); after all, Turkey itself, he thought, was "so strange a country" (Hamlin, 1877, p. iii), and the Turks had, throughout their history, been "a menace to Christendom" (Hamlin, 1877, p. 28). Moreover, he considered Islam to be a kind of "theology or demonology" (Hamlin, 1924, p. 276), which the Turks as "an unevangelized people" (Hamlin, 1877, . 196) and as "the Mohammedans" (Hamlin, 1924, p. 203) practised. Therefore, he strongly believed and maintained that, although the Muslims and the Muslim clergy were fanatically bound to the Koran as the word of God, and also despite the fact that "apostasy" as a Muslim's renunciation of his faith, and his conversion to another religion, was a most serious crime in the Ottoman penal code, subject to capital punishment (Hamlin, 1877, pp. 83-84), the evangelical conversion of the Muslim Turks as well as of the eastern Christians (the Armenians, the Greeks, and the Nestorians) was to be achieved through the philanthropic work of education and vocational training offered jointly with evangelical instruction (Hamlin, 1877, pp. 90, 196-204 and 218-19). In his discussion with the other mission leaders of the field policies and practices to be adopted and put into effect, he pointed out that, under the favourable social and political circumstances brought about by the 1839 and 1856 Ottoman imperial rescripts, which, historically, ushered in a wide range of civil liberties and institutional reforms throughout the Empire (Karal, 1995, pp. 170-84 and 248-52), this goal of the conversion of the Muslims and the eastern Christians could be achieved much more effectively through a 
combination of vocational education and evangelical instruction. Especially in the case of the Muslim Turks, he further argued, "so far as an evangelical Christianity reaches the Moslem mind, it disarms itself of its prejudices [against the Christian faith]" (Among the Turks 92). For him, in the implementation of the American missionary policies, "commere and the arts have no corrupting influence, when introduced to help forward a Christian life, and Christian work" (Hamlin, 1877, p. 203). Therefore, he concluded, "education, and the common industries of civilized life, must accompany, but not precede the Gospel, in order to have a church [for the converts of Turkey] with the three grand characteristics,-- 'self-governing', 'selfsupporting', and 'self-developing." (Hamlin, 1877, p. 204). Thus, his idea of the American missionary work in Turkey did not accommodate mere evangelism with no missionary involvement in the improvement of the economic, social and cultural life of the converts. Indeed, he regarded the missionary work as an integrated activity and practice of evangelism and philanthropy (Daniel, 1970, pp. 53-57 and 69-70). However, both the Boston headquarters of the missions and the great majority of the mission administrators in Turkey opposed Hamlin's idea of evangelism through philanthropy (Hamlin, 1877, pp. 196-204; Daniel, 1970, pp. 53-57 and 70). So, by way of a defence of his vision, he wrote in his memoirs that

some suppose that I have gone into secular and especially mechanical industries, in the evangelizing work, from a natural tendency that way. Nothing could be further from the truth. What I have done has been from the the imperious force of circumstances (Hamlin, 1877, p. 204).

Thus, through the philanthropic work of education, the converts would have the opportunity to acquire skills and techniques whereby they could set up a business and earn a decent living for a respectable life. Moreover, the philanthropic work as such would also justify and bolster the aims and practice of the missionary work. Hamlin reiterated this view of the use of the philanthropic work for the sucess of the evangelical mission as follows:

We, the missionaries, have protection, safety, and all the comfots of life. They [the converts] are persecuted by their own people. Some of them have been reduced from affluence to poverty, to beggary even; and their present life will never show to the world the Gospel in its true light. Until they can live by 
their own labor, and not by charity, their faith will not commend itself to others. To help them out of this condition is as truly a Christian work as healing the sick or restoring sight to the blind. Instead of blotting or blearing the missionary character, it will vindicate it (Hamlin, 1877, pp. 218-19).

So, by taking Hamlin's argument that the missionary work ought to be an integrated practice of philanthropy and evangelism, our purpose in this paper is both to describe his own philanthropic efforts through his missionary work and dwell on the philanthropic aspects of the American missionary activities in Turkey in the nineteenth century. In order for us to have a working framework of reference and situate our subject in a theoretical as a well as historical context, it would be useful to refer at the outset to the relationship between philanthropy as a secular activity and the missionary work as an evangelical practice and also describe the historical process of the initiation and development of the American missionary involvement in Turkey.

Robert L. Payton, whose seminars in the late 1970s and early 1980 s at Columbia University on volunteerism and voluntary work have led to the rise of philanthropy as a field of study and research (Lyman, 1988, p.ix), has defined philanthropy as "voluntary giving, voluntary service, and voluntary association primarily for the benefit of others" (Payton, 1988, p. 32). Metaphorically, he has called it "the prudent sister of charity" (Payton, 1988, p. 32). Moreover, he has emphasized that "the first law of philanthropy, like the first law of medicine, is Do no harm" (Payton, 1988, p. 28). The fact that a philanthropic work does not, and should not, for the donor of the service, aim at any kind of profit, whether economic or political, social, moral, and religious, is obvious from Payton's association of philanthropy with volunteerism and charity, whereby the giving self interacts, through a sense of fulfilment, with the receiving other so that, in the end, the quality of life for the other may be improved and upgraded in a way agreeable with human dignity. Payton calls this interaction between the giving self and the receiving other the philanthropic dialectic which, for him, operates through a compassionate and humanitarian nonprofit relationship (Payton, 1988, p. 39). In this respect, although he points out that, due to the varied norms and patterns of behaviour adopted by individuals, institutions, and organizations in the perception and practice of philanthropy, "philanthropy 
is not a firmly fixed and settled compendium of values and practices" (Payton, 1988, p. 32), one may further suggest with the nonprofit and noharm principles of philanthropy in mind that, in addition to charity, compassion, humanity and humanitarian concern, a philanthropic activity is also motivated and characterized by good consience, fairness, generosity, honesty, goodness and tenderness. Obviously, these are the same values which Payton may have meant through the ethical principles he has attributed to the American philanthropic organization "Independent Sector" (Payton, 1988, p. 27n); for him, these principles are "commitment beyond self, worth and dignity of the individual, individual responsibility, tolerance, freedom, justice, and responsibilites of citizenship" (Payton, 1988, pp. 33-34). If one recalls that Payton identifies religion, health, education, welfare, culture, and civic and community affairs as the "six major areas of philanthropic activity" (Payton, 1988, p. 39), one cannot refrain from posing the question whether the practice and demonstration of these principles in each of these six field may also embody other variants of purpose whereby the moral and humanitarian significance of the philanthropic work itself is subverted and distorted.

A relevant example in history of the difference as such between the theory and practice of philanthropy is obviously the American missionary work in Turkey and other parts of the Ottoman Empire in the nineteenth and early twentieth centuries. Principally, the question whether or not any missionary work, which in essence aims at proselytism and, hence, seeks a moral profit in cultural terms through the replacemnt and eradication of the native religion by the missionary's own religion, may also be regarded as a philanthropic activity, is certainly a matter of controversy, although some historians of the American missionary work in the Ottoman Empire have found it hard to make a distinction between the two. For instance, Daniel has acknowledged that it is impossible "to distinguish between the work carried out as an integral part of the missionary effort and the activities supported for humanitarian reasons. [...] Motives were often mixed" (Daniel, 1970, p.x).

However, it is not the immediate concern of this paper to problematize the issue further, and, as we have already stated, our concern here is to present a concise account of the philanthropic activities in which, along with their evangelical pursuits, Cyrus Hamlin in particular and the American 
missionaries in general were engaged in Turkey in the nineteenth century. The theoretical paradigms that will be taken into consideration in assessing the philanthropic aspects of the missionary work are those set down by Payton and referred to above.

Historically, the establishment of the American missionary services in Turkey was a natural outcome of the growing economic and political relations between the United States and the Ottoman Empire in the late eighteenth and early nineteenth centuries. Faced with the British and French diplomatic, commercial and navigational subversions (Allison, 1995, pp. 3-5 and $153 \mathrm{ff}$.), the early American administrations after the Revolution sought new measures to promote American international trade and expand foreign relations. Hence, as early as 1784 the Congress set up a special committee, consisting of John Adams, Benjamin Franklin, and Thomas Jefferson, to study and formulate policies and strategies for the establishment of relations with other friendly countries (Kocabaşoğlu, 1992, p. 66). The committee drew up a list of the sovereign states with which the United States could initiate diplomatic contacts and negotiations. In the list was also included Turkey, then the Ottoman Empire with Istanbul as its capital. For the United States, the establishment of relations with Turkey was of vital importance because, through such a rapprochement, the American merchant ships engaged in the Levant trade would be much more secure from the harassments of the British and French navies and, thus, gain "commercial freedom in the Mediterranean" (Allison, 1995, p. 155). Thus, economically, America would have safe access to the lucrative Smyrna [İzmir] and Black Sea trade potential, which was further to preoccupy the Monroe, Adams, and Jackson administrations in the early nineteenth century (Daniel, 1970, p. 3). Moreover, America needed the political and moral support of Turkey in a peaceful solution of the chronic political and maritime problems with the Barbary states of Algiers, Tunisia, and Tripoli [Libya], which were then under the suzerainty of the Ottoman sultan (Allison, 1995, pp. 3-34 and 153-85; Daniel, 1970, p. 3). Therefore, when the American frigate George Washington made the first official visit to Turkey in the late autumn of 1800 (Allison, 1995, pp. 175-77; Kocabaşoğlu, 1992, p. $66)$, this signified a turning point in the relations between the two states. As a gesture of goodwill towards friendship with the United States, the Ottoman Sultan, Selim III (1789-1808), received the frigate's commander Captain 
William Bainbridge in audience, who presented gifts to the sultan (Kocabaşoğlu, 1992, p. 66).

In fact, similar to the American expectations of Turkey, also the Turkish goverment in the early decades of the nineteenth century began to seek a political and economic alliance with the United States. Especially, during the Greek revolt in the 1820s, Turkey attached great importance and gave much urgency to such an alliance against the pressures of the European powers. Yet, due to the Monroe doctrine of no involvement in European affairs, the United States openly shunned any political alliance; instead, despite the strong and frantic anti-Turkish activities of the American philhellenes, a policy of quiet diplomacy was adopted towards Turkey for the protection of long-term American economic interests (Daniel, 1970, pp. 1-16). In the end, all these early political ouvertures and commercial expectations culminated in the signing, on 7 May 1830, of a commercial and maritime treaty between the two states. The treaty consisted of ten articles. The first nine articles spelt out the provisions made for the rights, privileges, exemptions, protection and free movement in Turkey of American merchants and commercial vessels, while the tenth article, which was a strictly confidential one, concerned the American military procurement and naval shipbuilding, which Turkey needed desperately (Armaoğlu, 1991, pp. 1-6). Follownig the treaty, the American naval architects Henry Eckfort and Foster Rhodes soon began work, in compliance with the tenth article, for the construction of a new Turkish navy in order to offset the 1827 Navarino disaster when the whole Turkish fleet had been destroyed by an allied force of the British, French, and Russian navies in support of the Greek revolt (Karal, 1995, p. 118; Armaoğlu, 1991, p. 1; Daniel, 1970, p. 280; Kocabaşoğlu, 1989, p. 11; Hamlin, 1877, p. 29). Then, in March 1831, the first American diplomatic mission was officially established in Istanbul. Obviously, all these diplomatic, political, and economic developments not only strengthened the relations between Turkey and the United States but they also opened up the Ottoman territories, first Lebanon and Syria, then followed by Turkey, and, later on, by Bulgaria, Albania, and Macedonia, for the introduction and expansion of the American missionary activities (Daniel, 1970, pp. 24-147).

Following its institutional incorporation in 1810 in Boston by the evangelical wing of the Congregational Church through the support of "likeminded men in both the Presbyterian Church and the Reformed Church" 
(Daniel, 1970, p. 18), the American Board of Commissioners for Foreign Missions (hereafter, cited as "the Board") immediately set to work by founding mission stations both at home and overseas. The Board's domestic missionary effort was mainly directed at the native Indian tribes, which in its initial stage included the Cherokees, the Choctaws and the Arkansas Indians (Daniel, 1970, p. 18). However, it was the foreign missions which the Board was keen to institute in what was often called in missionary literature heathendom or heathen lands (Martin, 1991, pp. 16 and 27). In this effort, much guidance and moral support for the Board came from the British missionary institutions, the Church Missionary Society and the British and Foreign Bible Society, which had also been engaged in evangelical proselyticism in Africa, Asia and the Middle East (Hamlin, 1924, p. 158; Daniel, 1970, pp. 18-19; Salt, 1993, p. 30). So the Board followed the same pattern of action and initially focused on Japan, China, the Indian subcontinent, Zululand in South Africa, and the Pacific islands from Hawaii to Fiji and Samoa. Then, in 1819, encouraged by the British evangelists in the area, the Board decided to establish missionary stations in the Middle East, then part of the Ottoman Empire. Thus, for the Board, the Gospel would be taken "back to the land where it came" (Daniel, 1970, p. 19). Viewed in terms of Protestant missionary politics, the Board's decision meant the dissemination of the true Christianity, represented in the Gospel, among the congregations of the eastern churches, which, for the Board, were superstitious and devoid of the teachings of the Gospel. The same perception was reiterated years later when Hamlin wrote that

The Christianity of the [Byzantine] empire was lost in drivelling superstitions. Magic and charms and relics and miraculous pictures, and holy fountains and places, were all that remained of the Gospel among the common people (Hamlin, 1877, p. $19)$.

It was also stressed in a later Board report that "the people in the area was in a state of deplorable ignorance and degradation, destitute of the means of divine knowledge and bewildered with vain imaginations and strong delusions" (Daniel, 1970, p. 19).

Therefore, as a preliminary step towards the establishment of missions in the Middle East, two young and dedicated missionaries, named Levi Parsons and Pliny Fisk, were sent to the area to make a full survey of the 
people and the circumstances (Daniel, 1970, pp. 18-21; Kocabaşoğlu, 1989, pp. 29-30; Salt, 1993, p. 30). They were also instructed "to suggest an appropriate course of action to authorities in Boston" (Daniel, 1970, p. 40). Their journey first took them to Turkey where they landed in Izmir about mid-January, 1820. So, in a way, they became the very first American missionaries to set foot on the Turkish soil. While in Izmir, they made a tour of the Biblical "seven churches" in the region (Rev. 1.20, 2.1, 8, 12, 18 and $3.1,7,14)$ and then travelled to the Holy Land as their assigned destination for missionary exploration. However, during this mission, Parsons died because of his poor health, and the survey was completed by Fisk in 1822 (Daniel, 1970, pp. 18-21). In the light of the Parsons-Fisk findings, the Board determined to expedite its missionary effort in the Middle East and, hence, appointed two of its senior missionaries, Isaac Bird and Dr William Goodell, in 1823 as the founders of the missions in Lebanon, Syria and Palestine, with Beirut as the mission headquarters (Daniel, 1970, pp. 24-40).

The establishment of missions in the Middle East was in fact the first stage of the missions that the Board envisaged to introduce into the Ottoman Empire. Hence, under the favourable circumstances brought about through the political and economic rapprochement between the United States and the Ottoman Empire, and also with the official inauguration in March 1831 of the American diplomatic mission in Istanbul, the Board took the initiative for the second stage of its missions and resolved to make Turkey the new field of the missionary effort, with Istanbul, like Beirut, as the regional headquarters. For this purpose, first of all, a survey of central and eastern Turkey together with the Caucasus and northwestern Iran was carried out from May 1830 to May 1831 by two senior missionaries, Eli Smith and Harrison Gray Otis Dwight. Their observations of the Armenian communities in particular provided the Board with vital information for the formulation of its policies of the missionary work to be undertaken in Turkey (Hamlin, 1877, pp. 148-49; Daniel, 1970, pp. 32 and 42-43; Kocabaşoğlu, 1989, pp. 38-39). In the meantime, in June 1831, only three months after the opening of the diplomatic mission, Goodell, transferred from Beirut, arrived in Istanbul as the first senior missionary commissoned to establish and coordinate the missions in Turkey (Daniel, 1970, pp. 42 and 44-46; Kocabaşoğlu, 1989, p. 38). Within a year, H.G.O. Dwight, William G. Schauffler, and Elias Riggs, as the other senior founding missionaries, joined Goodell in his work (Daniel, 1970, pp. 42-43 and 102). 
In the following years the number of the missionaries stationed in Turkey began to increase noticeably, reaching nearly a hundred by 1860 . With the training and recruitment of the native missionaries, the total number involved in the active missionary work went up rapidly (Daniel, 1970, p. 94; Kocabaşoğlu, 1989, p. 106).

During the first few years the missionary activities were mainly confined to the Greek, Armenian, and, somewhat selectively, Jewish communities in Istanbul. Yet, the Greek and Armenian patriarchal authorities, relying on the political and moral support of Russia, were extremely opposed to the loss of their own flock to Protestantism and, therefore, adopted a policy of attrition to forestall the efforts of the missionaries (Hamlin, 1877, pp. 30-37 and 6566; Daniel, 1970, pp. 48-51). The patriarchal opposition gradually lost its vigour partly due to the sectarian frictions among the Armenians themselves (Hamlin, 1877, p. 66) and, more importantly, due to the growing atmosphere of religious tolerance and freedom of conscience introduced by Sultan Mahmut II (1808-39), who was, in the latter part of his reign, determinedly committed to full modernization through radical reforms and the introduction into all aspects of social life of the values of European civilization (Hamlin, 1877, p. 47; Karal, 1995, pp. 143-64; Daniel, 1970, pp. 41-42). Furthermore, with the Imperial Rescript later in 1839, religious tolerance and freedom of conscience, especially for the non-muslim subjects of the Sultan, became absolute stipulations and received full recognition from the authorities (Hamlin, 1877, pp. 47-54; Karal, 1995, pp. 172-75).

Hence, encouraged by these political and social developments in the Empire, Goodell and his colleagues decided to carry their missionary activities to other parts of Turkey through the establishment of an increasing number of mission stations in the country. So, as Daniel (1970, p. 47) has explained,

by the end of the 1830's, mission stations and supporting schools, all at the elementary level, were spread across Asia Minor from Trebizond at the eastern end of the Black Sea to Urumia, Persia, near the Turkish frontier, to Caesarea [Kayseri] in the interior of Anatolia and Tarsus in the South.

It was right at this time when all these major changes were taking place in Turkish politics and social life, and also the expansion of the missionary 
work into the country was under way, that Cyrus Hamlin arrived in Istanibul and assumed his missionary responsibilities. Like his missionary colleagues, he was also primarily concerned with the dissemination of evangelicalism through proselytizing among the faithful of other creed. Naturally, he fully subscribed to the Board's policy that the ultimate aim of the missionary effort was to "establish Christian institutions of all kinds and organise an enlightened Christian society in all its departments" (Salt, 1993, p. 31). Hence, as we have pointed out above, he attached great importance to education and regarded it as an indispensable and most powerful means for the achievement of this goal. In other words, for him, mere evangelial preaching was far from being effective and, therefore, a philanthropic concern such as education was to be amalgamated with the ultimate evangelical purpose. His first attempt, as a perfect demonsration of this idea, was the founding in 1840, just one year after his arrival, of the Bebek Seminary in Istanbul, which was pragmatically to be the centre of "the evangelical movement in the oriental churches" (Hamlin, 1877, p. 61). Indeed, along with the evangelical instruction, the Seminary also offered vocational courses in various crafts and, thus, provided its students with the opportunity to acquire technical skills for their economic well-being. Hamlin strongly argued for what one may call philanthropic evangelism, and emphasized that it would be no deviation at all from the evangelical purpose of the missionary work to introduce "civilization when it is accompanied by the organization of the converts into a Christian church" (Hamlin, 1877, p. 203).

Undoubtedly, the most significant work, through which Hamlin's philanthropic perception of the missionary effort was fully realized, was Robert College in Istanbul, which was to be re-incorporated in 1971 as Bogazici [Bosphorus] University, today a most prestigious institution of higher education in Turkey. Originally, the idea of a college came not from Hamlin himself but, as we learn from his memoirs, from "the sons of my esteemed and beloved associate Dr. Dwight, the father of the mission" (Hamlin, 1877, p. 284). In 1856, a New York merchant, Christopher R. Robert, visited Istanbul and, during his stay, had contacts with the American missionary community. In his talks with them he was clearly much impressed by Hamlin's philanthropic evangelism and had a first-hand experience of his educational enterprises at the Seminary. On his return to the United States, he was approached by the Dwight brothers with a proposal for the 
establishment of an American college in Istanbul (Daniel, 1970, p. 72). With a philanthropic interest in the project, Robert turned to Hamlin to undertake the work. So from 1858 onwards Robert and Hamlin began to correspond about the project and reached an agreement in 1859 on the establishment of "a Christian college" in Istanbul, which Robert wanted to be non-denominational (Hamlin, 1877, pp. 284 and 285-86; Daniel, 1970, p. 72). Pedagogically, the college would, in perfect harmony with Hamlin's idea of philanthropic evangelism, "offer the best intellectual training, and as broad a culture as our best New England colleges" (Hamlin, 1877, p. 285). Hence, the curriculum was to be designed so as to encompass both evangelical instruction and secular vocational training. Accordingly,

the Scriptures would be the authoritative source of religious and moral instruction. The Gospel would be clearly and faithfully preached, the Bible read, and prayer offered morning and evening, but the rights of conscience would be held sacred. It would be a Christian college, preparing young men to enter upon professional study, or into any of the active pursuits of life (Hamlin, 1877, pp. 285-86).

However, Hamlin's involvement in such a project was not to the Board's pleasure since it was regarded as the neglect of his essential evangelial responsibilities. Moreover, the same view was shared implicitly, if not explicitily, by his leading missionary colleagues. So in 1860 he parted with the Board and the Istanbul mission, but he still considered himself an active American missionary in a differenet capacity:

In full harmony with this plan, the connection of twenty-two years with the American Board came to an end, but the work in which I had been engaged only assumed another form; and, on entering upon it, I considered myself more a missionary to Turkey than before. I was to labor, so far as possible, for all its people, without distinction of race, language, color, or faith (Hamlin, 1877, p. 286).

Thus, Hamlin finally felt relieved of the Board's rigid policy of evangelism directed at mere proselytizing and preaching, and turned into a humanist educator with a perception of philanthropic evangelism. 
Although Robert had personally promised to contribute $\$ 30.000$ towards the funding of the project, the college could only be incorporated in 1863 due to both the fund-raising problems during the Civil War and the redtape involved in the Turkish government's grant of building permission (Hamlin, 1877, pp. 287-95). In the meantime, after long deliberations on the names suggested for the college, among which were "American College, Anglo-American, Washington, the College of Bosphorus, Oxford (which [was] the translation of Bosphorus), and many other terms", the college was finally named as "Robert College" after its philanthropic benefactor (Hamlin, 1877, p. 291). Hamlin was appointed president but, owing to serious problems encountered in fund-raising, and, therefore, Robert's disillusionment with him, he was, after fourteen years in office, dismissed in 1877. He was succeded by his son-in-law George Washburn, who had also been a Board missionary in Istanbul and served as the mission treasurer from 1858 to 1868 . Under his able and innovative administration the College continued to thrive and prosper (Daniel, 1970, pp. 74-76).

Although, at the outset, the missionary administration in Istanbul, in compliance with the Board's evangelical policy, did not fully approve Hamlin's theory and practice of education and regarded missionary education mainly as a means of evangelical instruction and moral development, this policy changed radically in the later decades of the nineteenth century; at the schools, colleges, and seminaries, which were established at major missionary stations, the curriula included a number of secular courses ranging from humanities and sciences to paramedicel teaching, law and arts (Kocabaşoğlu, 1989, pp. 152-205). Thus, in the end, an amalgamation of evangelism and educational philanthropy became a common feature of the American missionary work in Turkey.

The missionary practice of philanthropy was also extended to health, social work, agriculture, animal husbandry, and similar other areas. For instance, in Sivas, which was a major missionary station in eastern Turkey, Henry S. West, who, assigned in 1859 , served as a mission doctor until his death of typhus in 1874, provided health care not only for the missionaries and their families in the area but also for the general public. In a letter his missionary colleague Albert W. Hubbard wrote home in 1874, West's philanthropic work and its favourable impact on the locals was described as follows: 
When Dr. is at home, his office is thronged nearly all the time. These native physicians do little but pow-wow, and play on the superstitions of the patients. Dr. West is skillful, especially as a surgeon, and he has been here now nearly fourteen years, so that he is well known and appreciated. Those that are really able to pay, he charges a little, nothing however compared with what is charged at home for the same treatment... He also has constantly under his care a class of native medical students to whom he gives lectures, never stopping for Christmas, New Years, Fourth of July-- only for Sabbaths... He has strong influence in the vicinity, and were it not for fear of their priests and friends, many not only of the Armenians but also the Mohammedans would declare themselves on the side of the missionaries (Martin, 1991, pp. 82-83).

So, to conclude, the American missionaries have been viewed in ambivalent terms. Some historians have seen them as the political agents and agitators, sponsored by Britain and the United States, to stir the ethnic and religious feelings of the non-muslim communities in the Ottoman Empire and, thus, provoke them into revolt, while others have interpreted them as dedicated philanthropists. As one can clearly see from their narratives and accounts, it is true that morally, culturally, and personally, most missionaries were prejudiced against Islam, Turkish life and institutions; they also regarded the eastern Christians in the Empire as the people lost in the wilderness and, hence, to be saved. Accordingly, instructed and commissioned by the Board, they made evangelical propaganda their primary concern and, for the achievement of their goal, used philanthropic services as a means. Yet, this does not mean that the philanthropic work carried out by the missionaries like Cyrus Hamlin and Henry S. West is to be ignored and that they ought to be condemned merely on account of their proselytizing and non-philanthropic activities. It must be acknowledged that, despite their cultural solipsism, often abusive and angry narratives, and engrained anti-Turkish prejudice, their philanthropic efforts in essence represented their commitment to self-sacrifice, charity, compassion, and humanitarian values, in the face of deadly epidemics like cholera, plague, pneumonia, typhus, and similar other infectious diseases, which, as one learns from their narratives, claimed a significant number of missionary lives in Turkey (Schauffler, 1887, pp. 108-122; Martin, 1991, pp. 83 and 304-05). 


\section{REFERENCES}

Allison, Robert J. (1995). The Crescent Obscured: The United States and the Muslim World, 1776-1815. New York: Oxford University Press.

Armaoğlu, Fahir (1991). Belgelerle Türk-Amerikan Münasebetleri [TurkishAmerican Relations through Documents]. Ankara: Türk Tarih Kurumu.

Daniel, Robert L. (1970). American Philanthropy in the Near East, 18201960. Athens, OH: Ohio University Press.

Hamlin, Cyrus. (1877). Among the Turks. New York: Carter. (1924). My Life and Times. 6th ed. Boston: Pilgrim.

Karal, Enver Ziya (1995). Nizam-1 Cedid ve Tanzimat Devirleri (1789-1856) [The Nizam-1 Cedid and Tanzimat Periods] 7th ed. Ankara: Türk Tarih Kurumu.

Kocabaşoğlu, Uygur (1989). Kendi Belgeleriyle Anadolu'daki Amerika: 19. Yüzyılda Osmanlı Imparatorluğu'ndaki Amerikan Misyoner Okulları [Through Their Own Docments, the America in Anatolia: The American Missionary Schools in the Ottoman Empire in the Nineteenth Century]. Istanbul: Arba.

(1992). "Doğu Sorunu Çerçevesinde Amerikan Misyoner Faaliyetleri" [The American Missionary Activities within the Context of the Eastern Question]. In Tarihi Gelişmeler Iç̧inde Türkiye'nin Sorunları Sempozyumu (Dün-Bugün-Yarın) (Bildiriler) [Symposium on the Problems of Turkey within Historical Developments (The Past-The Present-The Future) (Proceedings)], March 8-9, 1990, Hacettepe University, Ankara: Türk Tarih Kurumu (pp. 65-73).

Myman, Richard W. (1988). Preface. In Robert L. Payton, Philanthropy: Voluntary Action for the Public Good. New York: ACE/Macmillan (pp. ix-xiii).

Martin, Edwin M. (1991) The Hubbards of Sivas: A Chronicle of Love and Faith. Santa Barbara, CA: Fithian.

Payton, Robert L. (1988). Philanthropy: Voluntary Action for the Public Good. New York: ACE/Macmillan.

Salt, Jeremy. (1993). Imperialism, Evangelism and the Ottoman Armenians, 1878-1896. London: Cass.

Schaufffler, William G. (1887). Autobiography of William G. Schauffler, Forty-Nine Years A Missionary in the Orient. Ed. "His Sons". Introd. E.A. Park. New York: Randolph. 
